\title{
An Economic Study of the Most Important Egyptian Exports of Medicinal and Aromatic Crops
}

\author{
Dr. Mamdouh El-Badry Mohammed \\ Researcher- Agricultural \\ Economics Research Institute
}

\author{
Dr. Yasser Mohamed Adel \\ Pharmacist in central administration \\ of pharmaceutical affairs
}

\section{Prof. Susan Mustafa Ahmed \\ Professor Emeritus - Agricultural Economics Research Institute Agricultural Research Center Introduction:}

Increasing the value of agricultural imports comparing with agricultural exports are the main reason for increasing the deficit of agricultural trade balance by about 78.345 billion pounds in 2014, where the value of agricultural exports were about 36.711 billion pounds, while the value of agricultural imports reached about 115.06 billion pounds in 2014, the cover proportion of agricultural exports to Agricultural imports reached about $31.9 \%$ in 2014. This shows deficit of agricultural production for providing the growing needs of the population, increasing agricultural exports lead to reduce this deficit. The medicinal and aromatic plants are considered important crops where the production value to about 1.127 billion pounds representing about $0.4 \%$ of the value of agricultural production of about 282.4 billion pounds in 2014.

The Medicinal and Aromatic Plants are considered non-traditional agricultural crops, there are about 2,000 species, and it grows wild in the Nile Valley, the east desert, west and Sinai.More than 60 species, these plants are grown for medical and industrial purposes. medicinal and aromatic oils are considered of important industries, Egypt is characterized by a competitive advantage in the production and export of these products, whether raw material or derived oils, Egypt is the first ranked in the production of (a paste jasmine), reached about 57\% from the total world production which about 14 tons per annual, while fourth ranked in the total medicinal and aromatic oils exports.

Interest has increased of cultivation of medicinal and aromatic plants, to get the essential oils, intervention in the synthesis of many industrial vehicles, alternative to chemical cosmetics, herbs, therapeutic, Flavors, natural preservatives in the food industry, the pharmaceutical industry (eye drops), paints, cosmetics in shampoos manufacturing industry, creams, hair oils, fragrances, chemical industries such as the manufacture of soap, air freshener, pesticides, rose water, orange blossom water, water mint, etc., and therapeutic qualities characteristic, the pharmaceutical industry, pharmaceuticals, and in the composition of spices and various spices.

Total cultivated medicinal and aromatic plants area are reached 61.3 thousand faddan in the average (2000-2014) representing about $0.8 \%$ of the total cultivated area, which amounting about 7.9 million faddanin 2014. The crops (coriander, cumin, fennel, anise, marjoram, caraway, Eshieh, mint, jasmine, hibiscus) of the most aromatic plants crops, representing the value of exports of those crops about $8.38 \%$, $7.43 \%, 14.41 \%, 0.08 \%, 16.09 \%, 9.68 \%, 11.36 \%, 9.6 \%, 2.19 \%, 3.62 \%$ respectively 
Exports of Medicinal and Aromatic Crops

from the average of total medicinal and aromatic plants export, which reached about 113.1 million pounds during the average period (2000-2014).

\section{Research problem:}

Although the competitiveness of Egypt in the production and export of medicinal and aromatic plants, was cultivated area of these crops around 60.089 thousand Fadden in 2014, but the total of the most important medicinal and aromatic plants quantities are decreasing from about 21.21 thousand tons in 2000 to about 2.93 thousand tons in 2014, the export value of medicinal and aromatic these plants are has decreased, from about 55.24 million pounds in 2000, to about 41.75 million pounds in 2014, these calls results leads to study the economies of Egyptian exports of medicinal and aromatic plants, and trying to find foreign markets for those important export products.

\section{Research objectives:}

This study aimed at studying the exports of the most important medicinal and aromatic plants crops, i.e(coriander, basil, cumin, fennel, anise, marjoram, caraway, wormwood, mint, jasmine, hibiscus) through the study of the following sub-goals:

1- The uses of some medicinal and aromatic plants in the field of medicine and then extraction methods.

2- The present situation of production and exports for some medicinal and aromatic crops during the period (2000-2014).

3- Estimating the stability factor of the amount of Egyptian exports of the most important medicinal and aromatic plants.

4-Toexamine the Gini Coefficient - Hirschman using Geographical distribution of Egyptian exports to the most important medicinal and aromatic crops used in the field of pharmacy and medicine to the main importing countries during the period (2000-2014).

5- Forecasting the area, production, amount and the value of the most important Egyptian exports of medicinal and aromatic crops until 2020.

\section{Methodology and data sources:}

This study is based on estimating some descriptive measures which:analysis of time series, simple regression and annual rates of growth.

\section{$\begin{gathered}\text { Stability of the amount of Egyptian exports of medicinal } \\ \text { plants coefficient }\end{gathered} \frac{\mathrm{IY}_{\mathrm{t}}-\mathrm{Y}_{\mathrm{t}}^{\wedge} \mathrm{I}}{\mathrm{Y}_{\mathrm{t}}^{\wedge}}$
$\mathrm{X}$ 100}

\section{Where}

$\mathbf{Y}_{\mathbf{t}}$ : Refers to quantity or value of Egyptian exports from medicinal and aromatic crops.

$\mathbf{Y}_{\mathbf{t}}^{\wedge}$ : Refers to the amount or value estimated of Egyptian exports of medicinal and aromatic crops.

Where the instability coefficient isexpress for the comparative advantage and competitiveness of the country, if the parameter value equal to zero, this means that the stability of phenomenon, and the higher is indicates that the lack of consistency 
and stability, it was found that the economic stability for the amount of Egyptian exports of medicinal and aromatic crops which about $8.7 \%$ in 2000 , then increased to $75.5 \%$ in 2014 , an increase about $66.8 \%$ representing about $768.5 \%$ from 2000 , while showing that the economic stability of the value of Egyptian exports of medicinal and aromatic crops which about $4.4 \%$ in 2000, and then increased to about $9.9 \%$ in 2014 , an increase about $5.5 \%$ representing approximately $124.4 \%$ in 2000 . It is therefore concluded unsteadiness and instability for the quantity and the value of Egyptian exports of medicinal and aromatic cropsduring the period (2000-2014) - table (3).

As has been estimated Gini Coefficient - Hirschman, for calculating the degree of geographic concentration for the Egyptian exports of the most important studiedcrops to the main importing countries through the following equation:

\section{Where:}

$$
\mathrm{Cjx}=100 * \sqrt{\sum(\mathrm{Xsj} / \mathrm{Xi})^{2}}
$$

$\mathbf{C}_{\mathbf{J X}}=$ Geographic concentration coefficient for the quantity of Egyptian exports of the most important of medicinal and aromatic crops.

$\mathbf{X}_{\text {SJ }}$ Quantity of Egyptian exports of the most important medicinal and aromatic crops which directed to the country $\mathrm{j}$.

$\mathbf{X}_{\mathbf{J}}=$ Total of Egyptian exports quantity of the most important medicinal and aromatic crops.

$\mathbf{J}=$ the country which issued the medicinal and aromatic cropsfromi to $\mathrm{j}$.

It has been estimated the forecasting by using the Box-Jenkins models (ARIMA): It is a model based on extraction the average for the variable as a model for forecasting, but stationary the data both in terms of variation, or trend, then estimating residuals (random error) by using autoregression with moving average, as in the following equation:

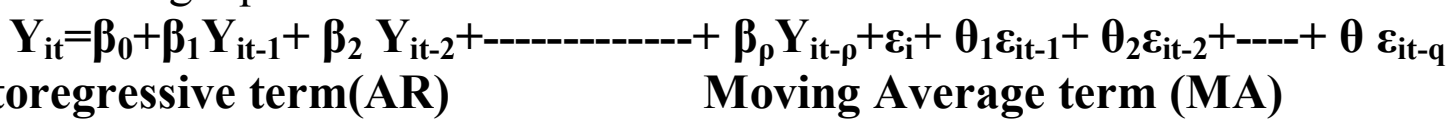
Autoregressive term(AR)

The study depended on the secondary data published in journals, pamphlets issued by the Ministry of Agriculture and land reclamation, Central Agency for Public Mobilization and Statistics, Food and Agriculture Organization (FAO), and the Arab Organization for Agricultural Development, and the use of some research, studies relevant to the present study.

\section{Extraction Technologies for Medicinal and Aromatic Plants ${ }^{(1)}$ :}

Medicinal plants are the richest bio resource of drugs for traditionalsystems of medicine, modern medicines, nutraceuticals, food supplements, folk medicines, pharmaceutical intermediates and chemical entities for synthetic drugs.

Aromatic plants are a source of fragrances, flavors, cosmeceuticals, health beverages and chemical terpenes.

(1)- Encyclopedia medicinal plants.

-Extraction-Technologies-for-Medicinal-and-Aromatic-Plants. 
Exports of Medicinal and Aromatic Crops

\section{The Extraction:}

Is active portions of plant (and animal) tissues using selective solvents through standard procedures is called the separation of medicinally. Such extraction techniques separate the soluble plant metabolites and leave behind the insoluble cellular marc.

The products so obtained from plants are relatively complex mixtures of metabolites, in liquid or semisolid state or (after removing the solvent) in dry powder form, and are intended for oral or external use.

These include classes of preparations known as decoctions, infusions, fluid extracts, tinctures, pilular (semisolid) extracts or powdered extracts

These products all contain complex mixture of many medicinal plant metabolites such as alkaloids, glycosides, terpenoids, flavonoids and lignans.

\section{The basic parameters influencing the quality of an extract:}

1. Plant parts used as starting material.

2. The solvent used in extraction.

3. The extraction technology.

4. Adherence to G.M.Ps.

\section{General Methods of Extraction of Medicinal Plants:}

\section{Maceration:}

In this process, the whole or coarsely powdered crude drug is placed in a stoppered container with the solvent and allowed to stand at room temperature for a period of at least 3 days with frequent agitation until the soluble matter has dissolved. The mixture then is strained, the marc (the damp solid material) is pressed, and the combined liquids are clarified by filtration or decantation after standing.

\section{Hydrolytic maceration:}

Maceration refers to the preparation of a solution by soaking plant material in vegetable oil or water. Maceration methods are based on the immersion of crude drug in bulk solvent

\section{3. infusion:}

Fresh infusions are prepared by macerating the crude drug for a short period of time with cold or boiling water. These are dilute solutions of the readily soluble constituents of crude drugs.

\section{Digestion:}

This is a form of maceration in which gentle heat is used during the process of extraction. It is used when moderately elevated temperature is not objectionable. The solvent efficiency of the menstruum is thereby increased.

\section{Decoction:}

In this process, the crude drug is boiled in a specified volume of water for a defined time; it is then cooled and strained or filtered. This procedure is suitable for extracting water-soluble, heat-stable constituents. This process is typically used in 
preparation of Ayurvedic extracts called "quath" or "kawath". The starting ratio of crude drug to water is fi xed, e.g.1:4 or 1:16; the volume is then brought down to onefourth its original volume by boiling during the extraction procedure. Then, the concentrated extract is filtered and used as such or processed further.

\section{Hydrodistillation:}

In order to isolate essential oils by hydro distillation, the aromatic plant material is packed in a still and a sufficient quantity of water is added and brought to a boil; alternatively, live steam is injected into the plant charge. Due to the influence of hot water and steam, the essential oil is freed from the oil glands in the plant tissue. The vapor mixture of water and oil is condensed by indirect cooling with water. From the condenser distillate flows into a separator, where oil separates automatically from the distillate water.

\section{High performance liquid chromatography (HLPC):}

The term liquid chromatography (LC) refers to a range of chromatographic systems, indicating liquid-solid, liquid-liquid,ion-exchange and size exclusion chromatography. Glass column chromatography is an example of classic liquid column chromatography in which the mobile phase percolates under gravity through a glass column filled with a finely divided stationary phase. Liquid chromatography has overtaken gas chromatography, as high performance liquid chromatography (HPLC) systems now provide features-Appendix (1) such as:

i) High resolving power

ii) Fast separation

iii) Continuous monitoring of column effluent

iv)Qualitative and quantitative measurements and isolation

v) Automation of analytical procedures and data handling

Estimating the trend models for the most important medicinal and aromatic plants crops:

Estimating the trend models for each of : production, quantity, and the value of medicinal and aromatic plants exports, in addition to the quantity, value and price per ton for exports of the most important medicinal and aromatic plants crops (coriander, cumin, fennel, anise, marjoram, caraway, Eshieh, mint, jasmine, Hibiscus) during the period (2000 to 2014), where the statistical evidence of the significant of the rates of change for all crops, the study shows, when the significant levels of the 0.05 tables $(1,2)$. The area of Medicinal and Aromatic Plants are reached increasing rate about $1.08 \%$ of average total production growth of the most important medicinal and aromatic plants, about $8.19 \%$ rate, while the total amount of medicinal and aromatic plants exports, achieved decreasing the growth rate, about $3.425 \%$, the medicinal plant exports and aromatic were about decreasing rate $1.95 \%$, during the study period - table (1)

Coriander crop: showing that the quantity of exports decreased at a decreasing rate about $5 \%$, the value of exports increased with an increase rate of about $9.6 \%$, the price per ton export is increasing at an increasing rate, about $12.9 \%$. As for the cumin: showing that the quantity of exports increased at an increasing rate about $5.8 \%$, the value of exports is increasing at an increasing rate, about $13 \%$, the price per 
Exports of Medicinal and Aromatic Crops

ton export is increasing at an increasing rate of, about $9.3 \%$ of the average during period - table (1).

Tab(1): Evolution of production, area and the Egyptian exports of the most important medicinal and aromatic plants during the period (2000-2014) (Area:

Thousand Fadden- production: tons -Value: million pounds)

\begin{tabular}{|c|c|c|c|c|c|c|c|}
\hline & $\mathbf{2 0 0 0}$ & $\mathbf{2 0 1 4}$ & Average & $\begin{array}{c}\text { Amount } \\
\text { Change }\end{array}$ & $\begin{array}{c}\text { Growth } \\
\text { Rate }\end{array}$ & $\mathrm{R}^{2}$ & $\mathrm{~F}$ \\
\hline $\begin{array}{c}\text { Medicinal and Aromatic } \\
\text { Plants Area }\end{array}$ & 53.347 & 60.09 & 61.27 & 0.663 & 1.082 & 0.242 & $4.1^{* *}$ \\
\hline Production & 108.5 & 395.4 & 257.4 & 21.08 & 8.189 & 0.874 & $90.2^{* *}$ \\
\hline $\begin{array}{c}\text { Exported Quantity } \\
\text { Exports Value of } \\
\begin{array}{c}\text { medicinal and aromatic } \\
\text { plants (true value) }\end{array}\end{array}$ & 129.21 & 2.93 & 15.74 & -0.539 & -3.425 & 0.287 & $5.2^{* *}$ \\
\hline
\end{tabular}

*Coefficients statistically significant at a significance level 0.01 .

**Coefficients statistically significant at a significance level 0.05 .

Source: collected and calculated from: Central Agency for Public Mobilization and Statistics, Bulletins of the Foreign Trade,www.capmas.gov.eg

Fennel crop: showing that the quantity of exports decreased at a decreasing rate to about $4 \%$, the value of exports increased with an increase rate of about $9.2 \%$, the price per ton export is increasing at an increasing rate about $7.8 \%$. As for anise: showing that the quantity of exports is decreasing at a decreasing rate to about $13.3 \%$, the value of exports is decreasing at a decreasing rate about $10.8 \%$, the price per ton export is increasing at an increasing rate, about $10.6 \%$ of the average during the period - table (1).

Marjoram crop: showing that the quantity of exports decreased at a decreasing rate to about $3.9 \%$, the value of exports is increasing at an increasing rate by about $5.1 \%$, the price per ton export is increasing at an increasing rate about $8.3 \%$. As for caraway, showing that the quantity of exports is increasing at an increasing rate by about $5.2 \%$, the value of exports is increasing at an increasing rate about $10.1 \%$, the price per ton export is increasing at a increasing rate to about $11.3 \%$ of the average during the period - table (1).

Eshieh crop: showing that the quantity of exports decreased at a decreasing rate to about $9.2 \%$, the value of exports increased at an increasing rate to about $6.6 \%$, the price per ton export increased at an increasing rate to about $4.1 \%$. As for mint: showing that the quantity of exports decreased at a decreasing rate to about $4.2 \%$, the value of exports increased at an increasing rate to about 7\%, the price per ton export increased at an increasing rate of about $8 \%$. As for jasmine showing that quantity of exports decreased at a decreasing rate to about $14 \%$, the value of exports decreased at a decreasing rate to about $10.8 \%$, the price per ton export increased at an increasing rate to about $15.2 \%$. As for hibiscus: showing that the quantity of exports increased at an increasing rate to about $14.1 \%$, the value of exports increased at an increasing rate to about $15.3 \%$, the price per ton export increased at an increasing rate to about $3.7 \%$ of the average during the study period-table (3).

We conclude from the foregoing a decreasing, in the quantity change rates of exports for most of medicinal and aromatic plants crops, exception of (cumin, caraway, Hibiscus) during the period (2000-2014). 
Tab (2): Evolution of Egyptian exports of the most important medicinal and aromatic plants during the period (2000-2014) (Quantity: tons -Value: 1000

pounds- Price: 1000 pounds/ton)

\begin{tabular}{|c|c|c|c|c|c|c|c|c|}
\hline plant & & 2000 & 2014 & Average & $\begin{array}{c}\text { Equations } \\
\end{array}$ & Growth Rate & $\mathrm{R}^{2}$ & $\mathrm{~F}$ \\
\hline Coriander & quantity & 3199 & 900 & 1544 & $\begin{array}{r}\hat{Y}=2157.3-76.71 \mathrm{~T} \\
(-2.69) *\end{array}$ & 5- & 0.358 & $7.3^{* *}$ \\
\hline value & & 5986 & 10990 & 9744 & $\begin{array}{c}\hat{\mathrm{Y}}=2233.1+938.8 \mathrm{~T} \\
(4.89)^{*}\end{array}$ & 9.6 & 0.648 & $23.9^{*}$ \\
\hline $\begin{array}{c}\text { price per } \\
\text { ton }\end{array}$ & & 1.87 & 12.21 & 7.15 & $\begin{array}{r}\hat{\mathrm{Y}}=0.224+0.921 \mathrm{~T} \\
(8.66)^{*}\end{array}$ & 12.9 & 0.852 & $75.0^{*}$ \\
\hline Cummins & quantity & 1110 & 550 & 783 & $\begin{array}{r}Y=411.6+45.46 \mathrm{~T} \\
(2.03)^{* * *}\end{array}$ & 5.8 & 0.241 & $4.1^{* *}$ \\
\hline value & & 3708 & 12565 & 10065 & $\begin{array}{r}\mathbf{Y}=440.1+1313.1 \mathrm{~T} \\
(4.07)^{*}\end{array}$ & 13 & 0.56 & $16.6^{*}$ \\
\hline $\begin{array}{c}\text { price per } \\
\text { ton }\end{array}$ & & 3.34 & 22.85 & 12.49 & $\begin{array}{r}\hat{Y}=3.22+1.158 \mathrm{~T} \\
(9.87)^{*}\end{array}$ & 9.3 & 0.882 & $97.4^{*}$ \\
\hline Fennel & quantity & 2296 & 215 & 2271 & $\begin{array}{c}\hat{\mathbf{Y}}=2771.1-90.057 \mathrm{~T} \\
(-2.11)^{* *}\end{array}$ & 4- & 0.253 & $4.4^{* * *}$ \\
\hline value & & 9046 & 2757 & 18356 & $\begin{array}{r}\mathrm{Y}=7723.1+1695.8 \mathrm{~T} \\
(4.76)^{*}\end{array}$ & 9.2 & 0.635 & $22.6^{*}$ \\
\hline $\begin{array}{l}\text { price per } \\
\text { ton }\end{array}$ & & 3.94 & 12.82 & 8.41 & $\begin{array}{r}\hat{\mathbf{Y}}=3.128+0.66 \mathrm{~T} \\
(28.76)^{*}\end{array}$ & 7.8 & 0.985 & 827.1* \\
\hline Anise & quantity & 194 & 40 & 101 & $\begin{array}{r}\hat{Y}=209.2-13.49 T \\
(-3.16)^{*}\end{array}$ & 13.3- & 0.435 & $10.0^{*}$ \\
\hline value & & 747 & 534 & 528 & $\begin{array}{r}\hat{Y}=997.9-57.04 T \\
(-2.12)^{* *}\end{array}$ & 10.8- & 0.258 & $4.5^{* *}$ \\
\hline $\begin{array}{c}\text { price per } \\
\text { ton }\end{array}$ & & 3.85 & 13.35 & & $\begin{array}{r}\bar{Y}=1.439+0.414 \mathrm{~T} \\
(2.1)^{* * *}\end{array}$ & 10.6 & 0.254 & $4.4^{* * *}$ \\
\hline Marjoram & quantity & 4092 & 165 & 2757 & $\begin{array}{r}Y=3616.8-107.5 T \\
(-2.63)^{* *}\end{array}$ & 3.9- & 0.347 & $6.9^{* * *}$ \\
\hline value & & 11837 & 1968 & 18900 & $\begin{array}{r}\hat{\mathbf{Y}}=11342+961.4 \mathrm{~T} \\
(2.62)^{* * *}\end{array}$ & 5.1 & 0.346 & $6.9^{* * *}$ \\
\hline $\begin{array}{c}\text { price per } \\
\text { ton }\end{array}$ & & 2.89 & 11.93 & 7.33 & $\begin{array}{c}\hat{\mathrm{Y}}=2.484+0.605 \mathrm{~T} \\
(15.59)^{*}\end{array}$ & 8.3 & 0.949 & $243.1^{*}$ \\
\hline Caraway & quantity & 1937 & 13 & 2300 & $\begin{array}{c}\hat{\mathrm{Y}}=1576.5+118.6 \mathrm{~T} \\
(2.80)^{*}\end{array}$ & 5.2 & 0.377 & $7.9^{* * *}$ \\
\hline value & & 4539 & 161 & 16478 & $\begin{array}{r}\hat{\mathbf{Y}}=3173.6+1663.1 \mathrm{~T} \\
(2.14)^{* *}\end{array}$ & 10.1 & 0.261 & $4.6^{* * *}$ \\
\hline $\begin{array}{c}\text { price per } \\
\text { ton }\end{array}$ & & 2.34 & 12.38 & 6.99 & $\begin{array}{r}\hat{Y}=0.683+0.788 \mathrm{~T} \\
(\mathbf{1 4 . 3 6})^{*}\end{array}$ & 11.3 & 0.941 & $206.3^{*}$ \\
\hline Eshieh & quantity & 2772 & 71 & 1875 & $\begin{array}{r}\hat{Y}=3256.7-172.7 T \\
(-5.44)^{*}\end{array}$ & 9.2- & 0.695 & $29.6^{*}$ \\
\hline value & & 9895 & 599 & 15050 & $\begin{array}{r}Y=23632-989.4 \mathrm{~T} \\
(-2.1)^{* *}\end{array}$ & 6.6- & 0.253 & $4.4^{* *}$ \\
\hline $\begin{array}{c}\text { price per } \\
\text { ton }\end{array}$ & & 3.57 & 8.44 & 8.27 & $\begin{array}{r}\hat{Y}=5.529+0.343 \mathrm{~T} \\
(3.23)^{*}\end{array}$ & 4.1 & 0.445 & $10.4^{*}$ \\
\hline Mint & quantity & 1280 & 209 & 1674 & $\begin{array}{r}\hat{Y}=2201.6-70.06 \mathrm{~T} \\
(-2.44)^{* *}\end{array}$ & 4.2- & 0.313 & $5.9^{* * *}$ \\
\hline value & & 3345 & 1825 & 11977 & $\begin{array}{r}\hat{\mathbf{Y}}=5304.6+834 \mathrm{~T} \\
(2.52)^{* *}\end{array}$ & 7 & 0.329 & $6.4^{* * *}$ \\
\hline $\begin{array}{c}\text { price per } \\
\text { ton }\end{array}$ & & 2.61 & 8.73 & 7.03 & $\hat{\mathrm{Y}}=2.535+0.562 \mathrm{~T}$ & 8 & 0.869 & $86.4^{*}$ \\
\hline Jasmine & quantity & 4180 & 85 & 1752 & $\begin{array}{r}Y=3715.6-245.5 \mathrm{~T} \\
(-2.71)^{*}\end{array}$ & 14- & 0.361 & $7.3^{* * *}$ \\
\hline the value & & 4909 & 1249 & 2908 & $\begin{array}{r}\hat{\mathbf{Y}}=5419.3-313.9 \mathrm{~T} \\
(-4.36)^{*}\end{array}$ & $10.8-$ & 0.594 & $19.0^{*}$ \\
\hline $\begin{array}{c}\text { price per } \\
\text { ton }\end{array}$ & & 1.17 & 14.69 & 4.43 & $\begin{array}{r}\hat{Y}=0.971+0.675 T \\
(3.33)^{*}\end{array}$ & 15.2 & 0.461 & $11.1^{*}$ \\
\hline Hibiscus & quantity & 150 & 680 & 680 & $\begin{array}{r}\hat{\mathbf{Y}}=87.86+95.93 \mathrm{~T} \\
(2.56)^{* *}\end{array}$ & 14.1 & 0.336 & $6.6^{* *}$ \\
\hline value & & 1228 & 9099 & 9099 & $\begin{array}{c}Y=2006+1388.2 \mathrm{~T} \\
(2.67)^{*}\end{array}$ & 15.3 & 0.355 & $7.1^{\text {k* }}$ \\
\hline $\begin{array}{l}\text { price per } \\
\text { ton }\end{array}$ & & 8.19 & 13.39 & 11.99 & $\begin{array}{r}\hat{\mathrm{Y}}=8.46+0.441 \mathrm{~T} \\
(2.6)^{*}\end{array}$ & 3.7 & 0.342 & $6.8^{* * *}$ \\
\hline
\end{tabular}

*Coefficients statistically significant at a significance level 0.01 .

$* *$ Coefficients statistically significant at a significance level 0.05 .

Source: collected and calculated from: Central Agency for Public Mobilization and Statistics, Bulletins of the Foreign Trade,www.capmas.gov.eg 
Exports of Medicinal and Aromatic Crops

Tab (3): Instability index for quantity and Value of the medicinal and aromatic plants exports during the period (2000-2014)

\begin{tabular}{|c|c|c|c|c|c|c|c|}
\hline & $\mathbf{2 0 0 0}$ & $\mathbf{2 0 1 4}$ & Average & $\begin{array}{c}\text { Amount } \\
\text { Change }\end{array}$ & $\begin{array}{l}\text { Growth } \\
\text { Rate }\end{array}$ & $\mathrm{R}^{2}$ & $\mathrm{~F}$ \\
\hline $\begin{array}{c}\text { Instability index for the } \\
\text { quantity of medicinal and } \\
\text { aromatic plants exports }\end{array}$ & 8.7 & 75.5 & 13.0 & 2.46 & 18.92 & 0.31 & $5.7^{* *}$ \\
$\begin{array}{c}\text { Instability index for the value } \\
\text { of medicinal and aromatic } \\
\text { plants exports }\end{array}$ & 4.4 & 9.9 & 9.6 & 0.149 & 1.55 & 0.02 & 0.002 \\
\hline
\end{tabular}

Source: collected and calculated from table no.(2).

The Geographic Distribution to Egyptian exports for the important medicinal and aromatic crops used in the field of pharmacy and medicine to the main importing countries through the average period (2008-2014)

Geographic distribution to Egyptian exports of the important medicinal and aromatic plants, used in the field of pharmacy and medicine (basil, marjoram, eshieh) for the purposes of Pharmacy or the purposes of Medicine, divided tonon-formatted for retail sale andformatted for retail sale for the main importing countries through the average period (2000-2014):

1- Geographic Distribution for Egyptian Exports of Basil Plant for the Purposes of Pharmacy to the Main Importing Countries during the period (2008-2014)

The total amount of basil for the purposes of Pharmacy exported are reached about 33.74thousandtons, with value about 431.55 million pounds, shows that the United States is first ranked, about 18.55 thousand tons representing $55 \%$, followed by Germany is about 3.36 thousand tons representing about $9.96 \%$, Canada about 1.60 thousand tons representing $4.73 \%$, followed by France, Russia, Poland, Italy, brazil, representing respectively $3.58 \%, 2.72 \%, 2.47 \%, 1.99 \%, 1.81 \%$ from the average total basil amount for the purposes of Pharmacy during the average period (2008-2014) -table (4).

Table (4): Geographic Distribution for Egyptian Exports of Basil for the

Pharmacy Purposes to the Main Importing Countries during the period (20082014) (value by true prices using wholesale price index 2010=100: million pound- Quantity: thousand tons)

\begin{tabular}{|l|c|c|c|c|}
\hline & $\begin{array}{c}\text { Value million } \\
\text { pounds }\end{array}$ & $\begin{array}{c}\text { Quantity } \\
\text { thousand tons }\end{array}$ & $\mathbf{\%}$ & $\begin{array}{c}\text { Price } \\
\mathbf{1 0 0 0} \text { pounds / ton }\end{array}$ \\
\hline United States of America & 248.59 & 18.55 & 54.99 & 13.40 \\
\hline Germany & 38.06 & 3.36 & 9.96 & 11.33 \\
\hline Canada & 19.54 & 1.60 & 4.73 & 12.25 \\
\hline France & 15.88 & 1.21 & 3.58 & 13.15 \\
\hline United Russia & 8.92 & 0.92 & 2.72 & 9.70 \\
\hline Poland & 8.37 & 0.83 & 2.47 & 10.06 \\
\hline Italia & 7.07 & 0.67 & 1.99 & 10.55 \\
\hline Brazil & 5.60 & 0.61 & 1.81 & 9.16 \\
\hline Total & $\mathbf{4 3 1 . 5 5}$ & $\mathbf{3 3 . 7 4}$ & $\mathbf{1 0 0}$ & $\mathbf{1 2 . 7 9}$ \\
\hline
\end{tabular}

Source: collected and calculated from: Central Agency for Public Mobilization and Statistics www.capmas.gov.eg 


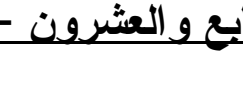

The average export price of basil plant for the purposes of Pharmacy is about 12.79 thousand pounds / ton, ranging from a minimum 8.02 thousand pounds / ton, and a maximum of 13.4 thousand pounds / ton during the study period.

\section{2- Geographic Distribution for Egyptian Exports of Basil non-formatted retail for the Medicine Purposes to the Main Importing Countries during the period (2008-2014)}

The total amount of basil was non-formatted for retail sale for the purposes of exporting medicine, are reached about 314 tons, with value about 3.75 million pounds, shows that the United States is first ranked in importing countries, about 120 tons representing about $38.22 \%$, followed by France is about 43 tons representing about $13.69 \%$; Italy about 40 tons representing about $12.74 \%$, followed by Turkey, Morocco, Ireland, Brazil, Spain, representing approximately $4.78 \%, 3.82 \%, 3.82 \%$, $3.50 \%, 3.18 \%$ respectively, of the average total basil amount of non-formatted for retail sale for the purposes of Medicine during the average period(2008-2014)-table (5).

Table (5): Geographic Distribution for Egyptian Exports of Basil non-formatted retail for the Medicine Purposes to the Main Importing Countries during the period (2008-2014) (value by true prices using wholesale price index 2010=100: million pound- Quantity: thousand tons)

\begin{tabular}{|l|c|c|c|c|}
\hline & $\begin{array}{c}\text { Value million } \\
\text { pounds }\end{array}$ & $\begin{array}{c}\text { Quantity } \\
\text { thousand tons }\end{array}$ & $\mathbf{\%}$ & $\begin{array}{c}\text { Price } \\
\mathbf{1 0 0 0} \text { pounds / ton }\end{array}$ \\
\hline United States of America & 1.71 & 0.12 & 38.22 & 14.28 \\
\hline France & 0.29 & 0.04 & 13.69 & 6.81 \\
\hline Italy & 0.46 & 0.04 & 12.74 & 11.56 \\
\hline Turkey & 0.17 & 0.02 & 4.78 & 11.10 \\
\hline Morocco & 0.12 & 0.01 & 3.82 & 9.63 \\
\hline Ireland & 0.21 & 0.01 & 3.82 & 17.79 \\
\hline Brazil & 0.11 & 0.01 & 3.50 & 9.97 \\
\hline Spain & 0.10 & 0.01 & 3.18 & 10.38 \\
\hline Total & $\mathbf{3 . 7 5}$ & $\mathbf{0 . 3 1}$ & $\mathbf{1 0 0}$ & $\mathbf{1 1 . 9 4}$ \\
\hline
\end{tabular}

Source: collected and calculated from: Central Agency for Public Mobilization and Statistics www.capmas.gov.eg

The average export price of plant basil non-formatted for retail sale for the purposes of Medicine is about 11.94 thousand pounds / ton, ranging from a minimum of 5.72 thousand pounds / tons to a maximum about 17.79 thousand pounds / ton during the study period.

3- Geographic Distribution for Egyptian Exports of Basil formatted retail for the Medicine Purposes to the Main Importing Countries during the period (2008-2014)

The total amount of basil unprepared for retail sale for the medicine purposes for exporting are reached amounted about 2.27thousandtons, with value about 26.17 million pounds, shows that the United States is first ranked in importing countries, about 1260 tons representing approximately 55.45\%, followed by Brazil, about 95 tons representing about $4.19 \%$, Germany about 86 tons representing about 3.79\%, followed by France, Russia, United Kingdom, Italy, Turkey, represented respectively about $3.66 \%, 3.13 \%, 2.91 \%, 2.78 \%, 2.78 \%$ of average total basil amount unprepared for retail sale for the medicine purposes during the average period (2008-2014) table(6). 
Exports of Medicinal and Aromatic Crops

The average export plant of basil unprepared for retail sale price for the Medicine purposes is about 11.54 thousand pounds / ton, ranging from a minimum of 4.6 thousand pounds / tons to a maximum of 14.2 thousand pounds / ton during the study period.

Table (6): Geographic Distribution for Egyptian Exports of Basil formatted retail for the Medicine Purposes to the Main Importing Countries during the period (2008-2014) (value by true prices using wholesale price index 2010=100: million pound- Quantity: thousand tons)

\begin{tabular}{|c|c|c|c|c|}
\hline & $\begin{array}{l}\text { Value million } \\
\text { pounds }\end{array}$ & $\begin{array}{c}\text { Quantity } \\
\text { thousand tons }\end{array}$ & $\%$ & $\begin{array}{c}\text { Price } \\
1000 \text { pounds / ton }\end{array}$ \\
\hline United States of America & 17.85 & 1.26 & 55.45 & 14.20 \\
\hline Brazil & 0.85 & 0.10 & 4.19 & 8.95 \\
\hline Germany & 0.75 & 0.09 & 3.79 & 8.74 \\
\hline France & 0.64 & 0.08 & 3.66 & 7.69 \\
\hline United Russia & 0.73 & 0.07 & 3.13 & 10.30 \\
\hline United kingdom & 0.64 & 0.07 & 2.91 & 9.73 \\
\hline Italy & 0.74 & 0.06 & 2.78 & 11.71 \\
\hline Turkey & 0.60 & 0.06 & 2.78 & 9.59 \\
\hline Total & 26.17 & 2.27 & 100 & 11.54 \\
\hline
\end{tabular}

Source: collected and calculated from: Central Agency for Public Mobilization and Statistics www.capmas.gov.eg

4- Geographic Distribution for Egyptian Exports of Marjoram for the Pharmacy Purposes to the Main Importing Countries during the period (2008-2014)

The total amount Marjoram for the purposes of Pharmacy for exportingare reached about 18.03 thousand tons, with value about 248.67 million pounds, shows that Poland is first ranked about 4.14 thousand tons, representing about $22.98 \%$, followed by Germany 4.0 thousand tons representing about $22.16 \%$, United States about 3.59 thousand tons, representing about $19.88 \%$, followed by Italy, the Netherlands, France, Belgium, Russia, representing approximately $4.41 \%$, 2.64\%, $2.59 \%, 2.5 \%, 2.0 \%$ respectively of the total average amount of marjoram for the Pharmacy purposes during the average period (2008-2014) -table (7).

The average export price of marjoram for the Pharmacy purposes is about 13.79 thousand pounds / ton, ranging from a minimum 8.91 thousand pounds / tons, to a maximum of 13.79 thousand pounds / ton during the study period.

Table (7): Geographic Distribution for Egyptian Exports of Marjoram for the Pharmacy Purposes to the Main Importing Countries during the period (20082014) (value by true prices using wholesale price index $2010=100$ : million

\begin{tabular}{|l|c|c|c|c|}
\hline & $\begin{array}{c}\text { Value million } \\
\text { pounds }\end{array}$ & $\begin{array}{c}\text { Quantity } \\
\text { thousand tons }\end{array}$ & $\begin{array}{c}\text { \% } \\
\mathbf{1 0 0 0} \text { pounds / ton }\end{array}$ \\
\hline Poland & 47.99 & 4.14 & 22.98 & 11.58 \\
\hline Germany & 53.28 & 4.00 & 22.16 & 13.33 \\
\hline United States America & 58.89 & 3.59 & 19.88 & 16.43 \\
\hline Italy & 11.21 & 0.80 & 4.41 & 14.08 \\
\hline Holland & 9.15 & 0.48 & 2.64 & 19.23 \\
\hline France & 8.41 & 0.47 & 2.59 & 18.01 \\
\hline Belgium & 6.45 & 0.45 & 2.50 & 14.34 \\
\hline United Russia & 4.53 & 0.36 & 2.00 & 12.60 \\
\hline \multicolumn{1}{|c|}{ Total } & $\mathbf{2 4 8 . 6 7}$ & $\mathbf{1 8 . 0 3}$ & $\mathbf{1 0 0}$ & $\mathbf{1 3 . 7 9}$ \\
\hline
\end{tabular}

Source: collected and calculated from: Central Agency for Public Mobilization and Statistics www.capmas.gov.eg 
5- Geographic Distribution for Egyptian Exports of Marjoram non-formatted retail for the Medicine Purposes to the Main Importing Countries during the period (2008-2014)

The total amount Marjoram non-formatted for retail sale of the medicine purposes of exporting are reached about 190 tons, with value about 3.26 million pounds, shows that the United States is first ranked about 58 tons representing about $31.35 \%$, followed by France 21 tons representing 11.35\%, Italy about 19 tons representing $10.27 \%$, followed by Tunisia, Germany, Libya, Morocco, Israel, representing approximately $9.73 \%, 7.03 \%, 4.32 \%, 3.78 \%, 3.24 \%$ of average total amount Marjoram non-formatted for retail sale of the Medicine purposes during the average period (2008-2014) -table (8).

The average export price for non- formatted marjoram for retail sale of the Medicine purposes is about 17.61 thousand pounds / ton, ranging from a minimum 9.72 thousand pounds / tons, to a maximum of 23.62 thousand pounds / ton during the study period.

Table (8): Geographic Distribution for Egyptian Exports of Marjoram nonformatted retail for the Medicine Purposes to the Main Importing Countries during the period (2008-2014) (value by true prices using wholesale price index 2010=100: million pound- Quantity: thousand tons)

\begin{tabular}{|c|c|c|c|c|}
\hline & $\begin{array}{c}\text { Value million } \\
\text { pounds }\end{array}$ & $\begin{array}{c}\text { Quantity } \\
\text { thousand tons }\end{array}$ & $\%$ & $\begin{array}{c}\text { Price } \\
\mathbf{1 0 0 0} \text { pounds / ton }\end{array}$ \\
\hline United States of America & 1.03 & 0.06 & 31.35 & 17.76 \\
\hline France & 0.21 & 0.02 & 11.35 & 9.89 \\
\hline Italy & 0.37 & 0.02 & 10.27 & 19.38 \\
\hline Tunisia & 0.43 & 0.02 & 9.73 & 23.62 \\
\hline Germany & 0.25 & 0.01 & 7.03 & 19.21 \\
\hline Libya & 0.16 & 0.01 & 4.32 & 19.96 \\
\hline Morocco & 0.14 & 0.01 & 3.78 & 20.01 \\
\hline Israel & 0.09 & 0.01 & 3.24 & 15.34 \\
\hline Toal & 3.26 & 0.19 & 100 & 17.61 \\
\hline
\end{tabular}

Source: collected and calculated from: Central Agency for Public Mobilization and Statistics www.capmas.gov.eg

6-Geographic Distribution for Egyptian Exports of Marjoram formatted retail for the Medicine Purposes to the Main Importing Countries during the period (2008-2014)

The total amount of exporting Marjoram formatted for retail sale for the medicine purposes are reached about 910 tons, with value about 13.38 million pounds, show that Germany is the first ranked about 232 tons representing approximately $25.61 \%$, followed by Saudi Arabia 128 tons representing $14.13 \%$, United States about 122 tons representing $13.47 \%$, followed by France, Poland, Belgium, Brazil, Italy, representing about $7.40 \%, 6.18 \%, 4.86 \%, 3.97 \%, 3.20 \%$ of average total amount Marjoram formatted for retail sale for the medicine purposes during the period (2008-2014) - table (9).

The average export price for the formatted Marjoram for retail sale for the Medicine purposes is about 14.77 thousand pounds / ton, ranging from a minimum of 8.69 thousand pounds / tons, to a maximum of 18.66 thousand pounds / ton during the study period. 
Exports of Medicinal and Aromatic Crops

Table (9): Geographic Distribution for Egyptian Exports of Marjoram formatted retail for the Medicine Purposes to the Main Importing Countries during the period (2008-2014) (value by true prices using wholesale price index 2010=100: million pound- Quantity: thousand tons)

\begin{tabular}{|l|c|c|c|c|}
\hline & $\begin{array}{c}\text { Value million } \\
\text { pounds }\end{array}$ & $\begin{array}{c}\text { Quantity } \\
\text { thousand tons }\end{array}$ & $\begin{array}{c}\text { \% } \\
\mathbf{1 0 0 0} \text { pounds / ton }\end{array}$ \\
\hline Germany & 3.53 & 0.23 & 25.61 & 15.20 \\
\hline Saudi Arabia & 2.39 & 0.13 & 14.13 & 18.66 \\
\hline United States America & 2.10 & 0.12 & 13.47 & 17.22 \\
\hline France & 0.57 & 0.07 & 7.40 & 8.54 \\
\hline Poland & 0.67 & 0.06 & 6.18 & 12.05 \\
\hline Belgium & 0.59 & 0.04 & 4.86 & 13.38 \\
\hline Brazil & 0.44 & 0.04 & 3.97 & 12.16 \\
\hline Italy $\quad 0.45$ & 0.03 & 3.20 & 15.67 \\
\hline \multicolumn{1}{|c|}{ Total } & $\mathbf{1 3 . 3 8}$ & $\mathbf{0 . 9 1}$ & $\mathbf{1 0 0}$ & $\mathbf{1 4 . 7 7}$ \\
\hline
\end{tabular}

Source: collected and calculated from: Central Agency for Public Mobilization and Statistics www.capmas.gov.eg

7- Geographic Distribution for Egyptian Exports of Eshieh for the Pharmacy Purposes to the Main Importing Countries during the period (2008-2014)

The total amount of exporting Eshieh for the Pharmacy purposes are reached about 5.33 thousandtons, with value about 83.65 million pounds, shows that Germany is the first ranked about 1574 tons representing approximately $29.52 \%$, followed by Latvia 762 tons representing $14.29 \%$, Netherlands 568 tons representing $10.65 \%$, followed by United States, Venezuela, Ukraine, Spain, Morocco, representing approximately $6.04 \%, 5.18 \%, 5.03 \%, 4.5 \%, 3.19 \%$ respectively of the average total quantity of Eshieh for the pharmacy purposes during the average period ( 20082014)- table(10).

The average export price of Eshieh for the Pharmacy purposes is about 15.31 thousand pounds / ton, ranging from a minimum about 6.52 thousand pounds / tons, to a maximum of 24.15 thousand pounds / ton during the study period.

Table (10): Geographic Distribution for Egyptian Exports of Eshieh for the Pharmacy Purposes to the Main Importing Countries during the period (20082014) (value by true prices using wholesale price index 2010=100: million pound- Quantity: thousand tons)

\begin{tabular}{|l|c|c|c|c|}
\hline & $\begin{array}{c}\text { Value million } \\
\text { pounds }\end{array}$ & $\begin{array}{c}\text { Quantity } \\
\text { thousand tons }\end{array}$ & $\begin{array}{c}\text { \% } \\
\mathbf{1 0 0 0} \text { pounds / ton }\end{array}$ \\
\hline Germany & 25.94 & 1.57 & 29.52 & 16.48 \\
\hline Republic of Latvia & 9.38 & 0.76 & 14.29 & 12.31 \\
\hline Holland & 7.48 & 0.57 & 10.65 & 13.16 \\
\hline United States America & 7.68 & 0.32 & 6.04 & 23.86 \\
\hline Venezuela & 6.67 & 0.28 & 5.18 & 24.15 \\
\hline Republic of Ukraine & 2.36 & 0.27 & 5.03 & 8.82 \\
\hline Spain & 2.88 & 0.24 & 4.50 & 12.02 \\
\hline Morocco & 1.09 & 0.17 & 3.19 & 6.40 \\
\hline \multicolumn{1}{|c|}{ Total } & $\mathbf{8 1 . 6 5}$ & $\mathbf{5 . 3 3}$ & $\mathbf{1 0 0}$ & $\mathbf{1 5 . 3 1}$ \\
\hline
\end{tabular}

Source: collected and calculated from: Central Agency for Public Mobilization and Statistics www.capmas.gov.eg

8-Geographic Distribution for Egyptian Exports of Eshieh non-formatted retail for the Medicine Purposes to the Main Importing Countries during the period (2008-2014)

The total amount of exporting of Eshiehwas non-formatted for retail sale for the medicine purposes are reached about 173 tons, with value about 2.67 million 
pounds, shows that the Russian Federation was ranked about 43 tons representing approximately $24.86 \%$, followed by Spain 31 tons representing $17.92 \%$, Latvia 27 tons representing $15.61 \%$,followed by Jordan, Italy, Israel, Greece, Ukraine, representing approximately $9.25 \%, 9.25 \%, 5.20 \%, 4.62 \%, 4.05 \%$ of average total quantity of Eshiehnon-formatted for retail sale for the Medicine purposes during the average period (2008-2014) -table (11).

The average export price of plant Eshiehnon-formatted retail for the Medicine purposes is about 15.43 thousand pounds / ton, ranging from a minimum of 4.97 thousand pounds / tons, to a maximum of 21.55 thousand pounds / ton during the study period.

Table (11): Geographic Distribution for Egyptian Exports of Eshieh nonformatted retail for the Medicine Purposes to the Main Importing Countries during the period (2008-2014) (value by true prices using wholesale price index 2010=100: million pound- Quantity: thousand tons)

\begin{tabular}{|l|c|c|c|c|}
\hline & $\begin{array}{c}\text { Value million } \\
\text { pounds }\end{array}$ & $\begin{array}{c}\text { Quantity } \\
\text { thousand tons }\end{array}$ & $\mathbf{\%}$ & $\begin{array}{c}\text { Price } \\
\mathbf{1 0 0 0} \text { pounds / ton }\end{array}$ \\
\hline United Russia & 0.39 & 0.043 & 24.86 & 9.07 \\
\hline Spain & 0.55 & 0.031 & 17.92 & 17.60 \\
\hline Republic of Latvia & 0.41 & 0.027 & 15.61 & 15.16 \\
\hline Jordan & 0.34 & 0.016 & 9.25 & 21.55 \\
\hline Italy & 0.31 & 0.016 & 9.25 & 19.53 \\
\hline Israel & 0.16 & 0.009 & 5.20 & 17.41 \\
\hline Greece & 0.16 & 0.008 & 4.62 & 20.45 \\
\hline Republic of Ukraine & 0.08 & 0.007 & 4.05 & 10.77 \\
\hline \multicolumn{1}{|c|}{ Total } & $\mathbf{2 . 6 7}$ & $\mathbf{0 . 1 7 3}$ & $\mathbf{1 0 0}$ & $\mathbf{1 5 . 4 3}$ \\
\hline
\end{tabular}

Source: collected and calculated from: Central Agency for Public Mobilization and Statistics www.capmas.gov.eg

9- Geographic Distribution for Egyptian Exports of Eshieh formatted retail for the Medicine Purposes to the Main Importing Countries during the period (2008-2014)

Total amount of exporting Eshiehunprepared for retail sale for the medicine purposes are reached about 1.766 thousand tons, with value about 16.78 million pounds, shows that Germany is the first rankedabout 0.57 thousand tons representing $32.28 \%$, followed by Spain about 0.277 thousand tons representing $15.69 \%$, Jordan 0.155 thousand tons representing $8.78 \%$, followed by Venezuela, Netherlands, Italy, Russia, United States representing about respectively 7.13\%, 5.15\%, 3.91\%, 3.79\%, $3.40 \%$ of average total quantity of Eshiehunprepared for retail sale for the medicine purposes during the average period (2008-2014 )-table (12).

The average export price Eshiehunprepared for retail sale for the Medicine purposes is about 9.5 thousand pounds / ton, ranging from a minimum 6.07 thousand pounds / tons, to a maximum of 15.66 thousand pounds / ton during the study period.

From the review of the geographical distribution of Egyptian exports from the most important medicinal and aromatic plants, whether for the purposes of Pharmacy or for the Medicine, the two non-formatted for sale and formatted for retail sale for the purposes of Medicine to the main importing countries through the period average (2008-2014) that: the export price to be used for the purposes of Pharmacy, exceeds the purposes of Medicine, in each of basil, Eshieh except the Marjoram, it has been 
Exports of Medicinal and Aromatic Crops

shown that the price of a ton export from non-formatted Marjoram for retail sale for the Medicine purposes, more than that for the purposes of Pharmacy, and this calls for needing to direct focus to cultivate those plants for sale for the purposes of Pharmacy.

Table (12): Geographic Distribution for Egyptian Exports of Eshieh formatted retail for the Medicine Purposes to the Main Importing Countries during the period (2008-2014) (value by true prices using wholesale price index 2010=100: million pound- Quantity: thousand tons)

\begin{tabular}{|l|c|c|c|c|}
\hline & $\begin{array}{c}\text { Value million } \\
\text { pounds }\end{array}$ & $\begin{array}{c}\text { Quantity } \\
\text { thousand tons }\end{array}$ & $\mathbf{\%}$ & $\begin{array}{c}\text { Price } \\
\mathbf{1 0 0 0} \text { pounds / ton }\end{array}$ \\
\hline Germany & 4.53 & 0.570 & 32.28 & 7.95 \\
\hline Spain & 2.47 & 0.277 & 15.69 & 8.91 \\
\hline Jordan & 1.53 & 0.155 & 8.78 & 9.88 \\
\hline Venezuela & 0.99 & 0.126 & 7.13 & 7.85 \\
\hline Holland & 0.73 & 0.091 & 5.15 & 8.05 \\
\hline Italy & 1.02 & 0.069 & 3.91 & 14.79 \\
\hline United Russia & 1.05 & 0.067 & 3.79 & 15.66 \\
\hline United States of America & 0.56 & 0.060 & 3.40 & 9.35 \\
\hline \multicolumn{1}{|c|}{ Total } & $\mathbf{1 6 . 7 8}$ & $\mathbf{1 . 7 6 6}$ & $\mathbf{1 0 0}$ & $\mathbf{9 . 5 0}$ \\
\hline
\end{tabular}

Source: collected and calculated from: Central Agency for Public Mobilization and Statistics www.capmas.gov.eg

The Geographic Concentration of Egyptian Exports to the most important medicinal and aromatic plants used in the field of pharmacy and medicine to the main importing countries through the average for the period (2008-2014)

This part of this study deals the geographical concentration of Egyptian exports to the most important medicinal and aromatic plants used in the field of pharmacy and medicine, which include (basil, marjoram, Eshieh), both for the Pharmacy purposes or for the Medicine purposes, whereit divided the uninitialized for retail, formatted for retail sale for the main of importing countries during the period (20082014):

1- Geographical concentration of Egyptian exports of basil for the Pharmacy purposes to the main importing countries during the period (2008-2014)

Showing the Geographical Concentration of Egyptian exports from the basil, for the Pharmacy purposes, to United States, Germany, Canada, and France about $54.75 \%, 10.09 \%, 4.7 \%, 3.38 \%$ respectively, while about $2.82 \%, 2.48 \%, 1.88 \%$, $1.92 \%$ for Russian Federation, Poland, Brazil, Italy, respectively, through the average period (2008-2014) - table (13).

2-Geographical concentration of Egyptian exports of non- formatted basil for retail sale for the Medicine purposes to the main importing countries during the period (2008-2014)

Showing the geographic Concentration of Egyptian exports from the basil nonformatted for selling by retail for the medicine purposes to United States, France, Italy, Turkey about $34.72 \%, 21.42 \%, 10.74 \%, 7.15 \%$ respectively, while about 2.11 $\%, 2.05 \%, 2 \%, 1.84 \%$ for Morocco, Ireland, Brazil, Spain, respectively, during average period (2008-2014) - table (13). 
3-The geographic concentration of Egyptian exports of basil, unprepared for retail sale for the purposes of Medicine, to the main importing countries during the period (2008-2014)

Showing the geographic Concentration of Egyptian exports of basil, formatted for selling by retail for the Medicine purposes, to each of United States, France, Brazil, Netherlands about 58.79\%, 6.6\%, 3.87\%, 3.85\% respectively, while reached about $3.44 \%, 3.26 \%, 2.58 \%, 2.45 \%$ for Turkey, Germany, United Kingdom, Italy, respectively, during average period (2008-2014) - table (13).

4-The geographic concentration of Egyptian exports of marjoram for the Pharmacy purposes to the main importing countries during the period (20082014)

Showing the geographic Concentration of Egyptian exports of marjoram for the Pharmacy purposes, to each of Poland, Germany, USA, Italy about $23.05 \%$, $22.2 \%, 20.07 \%, 4.37 \%$ respectively, while reached about $2.59 \%, 2.58 \%, 2.45 \%$, $1.95 \%$ for France, Holland, Belgium, Russia, respectively, during average period (2008-2014) - table (13).

5-The geographic concentration of Egyptian exports of non Marjoram formatted for retail sale for the purposes of Medicine to the main importing countries during the period (2008-2014)

Showing the geographic Concentration of Egyptian exports of marjoram, nonformatted for selling by retail for the Medicine purposes, to each of United States, Israel, Germany, France about 20.87\%, 15.79\%, 14.44\%, 13.9\% respectively, while reached about $7.71 \%, 4.66 \%, 1.99 \%, 1.78 \%$ for Tunisia, Italy, Libya, Morocco, respectively, during average period (2008-2014) - table (13).

6-The geographic concentration of Egyptian exports of marjoram unprepared for retail sale for the purposes of Medicine to the main importing countries during the period (2008-2014)

Showing the geographic Concentration of Egyptian exports of marjoram, formatted for selling by retail for the medicine purposes, to each of Germany, USA, Poland, France about 29.48\%, 14.39\%, 10.63\%, 6.84\% respectively, while reached about $6.25 \%, 4.75 \%, 3.71 \%, 3.42 \%$ for Belgium, Italy, Brazil, Spain, respectively, during average period (2008-2014) - table (13).

7-The geographic concentration of Egyptian exports of Eshiehfor the Pharmacy purposes to the main importing countries during average period (2008-2014)

Showing the geographic concentration of Egyptian exports of Eshiehfor the Pharmacy purposes, to each of Germany, the Republic of Latvia, Netherlands, United States about $28.79 \%, 14.8 \%, 9.93 \%, 6.43 \%$ respectively, while reached about $6 \%$, $5.8 \%, 4.34 \%, 2.87 \%$ for Venezuela, Ukraine, Spain, Morocco respectively, during average period (2008-2014) - table (13).

8-The geographic concentration of Egyptian exports of Eshiehnon-formatted for retail sale for the Medicine purposes to the main importing countries during average period (2008-2014)

Showing the geographic concentration of Egyptian exports of Eshieh nonformatted for selling by retail for the Medicine purposes, to each of Spain, Russia, 
Exports of Medicinal and Aromatic Crops

Jordan, the Republic of Latvia about 27.58\% 0.25\%, 19.27\%, 6.96\% respectively, while reached about $4.2 \%, 4.11 \%, 2.3 \%, 1.81 \%$ for Greece, Italy, Israel, Ukraine respectively, during average period (2008-2014) - table (13).

9-The geographic concentration of Egyptian exports of Eshieh formatted for retail sale for the Medicine purposes to the main importing countries during average period (2008-2014)

Showing the geographic concentration of Egyptian exports of Eshieh formatted for selling by retail for the Medicine purposes, to each of Spain, Germany, Jordan, Italy about 23.36\%, 18.82\%, 10.79\%, 5.81\% respectively, while reached about $2.69 \%, 2.45 \%, 2.42 \%, 1.53 \%$ for Netherlands, United States of America and Venezuela respectively, during average period (2008-2014) - table (13).

A review of the results of concentration geographical Egyptian exports from the most important medicinal and aromatic plants, whether for the Pharmacy purposes or Medicine purposes, non-formatted for sale and formatted for retail sale, to the main importing countries during the average period (2008 -2014): for the basil plant, showing a concentration geographic for Egyptian exports from the basil for the Pharmacy purposes, to each of United States, Germany, Canada, France, about $72.9 \%$, and the other of the countries about $27.1 \%$, having a concentration geographic exports from the basil, non-formatted for retail sale, for the Medicine purposes, to each of United States, France, Italy, Turkey, about 74\%, and the other of the countries about $26 \%$, having a concentration geographic exports from the basil, formatted for retail sale, for the Medicine purposes, to each of United States, France, Brazil, Netherlands about $73.1 \%$, and the other of the countries about $26.9 \%$.

Table (13): Hirschman's Gini coefficient for Geographical Concentration of Egyptian Exports of the Most Important Medicinal and Aromatic Plants to the Main Importing Countries during average period (2008-2014)

\begin{tabular}{|c|c|c|c|c|c|c|c|c|c|c|c|c|c|c|c|c|c|}
\hline \multicolumn{2}{|c|}{$\begin{array}{l}\text { Basil for the } \\
\text { purposes of } \\
\text { Pharmacy }\end{array}$} & \multicolumn{2}{|c|}{$\begin{array}{c}\text { Basil non- } \\
\text { formatted for } \\
\text { retail sale for the } \\
\text { purposes of } \\
\text { medicine }\end{array}$} & \multicolumn{2}{|c|}{$\begin{array}{l}\text { Basil unprepared } \\
\text { for retail sale for } \\
\text { the purposes of } \\
\text { medicine }\end{array}$} & \multicolumn{2}{|c|}{$\begin{array}{l}\text { Marjoram for } \\
\text { the purposes of } \\
\text { Pharmacy }\end{array}$} & \multicolumn{2}{|c|}{$\begin{array}{c}\text { Marjoram non- } \\
\text { formatted for } \\
\text { retail sale for the } \\
\text { purposes of } \\
\text { Medicine }\end{array}$} & \multicolumn{2}{|c|}{$\begin{array}{l}\text { Marjoram } \\
\text { unprepared for } \\
\text { retail sale for the } \\
\text { purposes of } \\
\text { medicine }\end{array}$} & \multicolumn{2}{|c|}{$\begin{array}{l}\text { Eshieh for the } \\
\text { purposes of } \\
\text { Pharmacy }\end{array}$} & \multicolumn{2}{|c|}{$\begin{array}{l}\text { Eshieh non- } \\
\text { formatted for } \\
\text { retail sale for the } \\
\text { purposes of } \\
\text { Medicine }\end{array}$} & \multicolumn{2}{|c|}{$\begin{array}{c}\text { Eshieh } \\
\text { unprepared for } \\
\text { retail sale for the } \\
\text { purposes of } \\
\text { Medicine }\end{array}$} \\
\hline \begin{tabular}{l|} 
America \\
\end{tabular} & 54.75 & America & 34.72 & America & 58.79 & Poland & 23.1 & America & 20.87 & Germany & 29.48 & Germany & 28.79 & Russia & 25.00 & Germany & 18.82 \\
\hline Germany & 10.09 & Italy & 10.74 & France & 6.60 & Germany & 22.20 & Italy & 4.66 & Saudi & 10.63 & Latvia & 14.80 & Latvia & 6.96 & Venezuela & 2.42 \\
\hline Canada & 4.70 & France & 21.42 & Russia & 2.43 & America & 20.1 & France & 13.90 & America & 14.39 & Belgium & 1.80 & Italy & 4.11 & Spain & 23.36 \\
\hline France & 3.38 & $\begin{array}{l}\text { Morocco } \\
\end{array}$ & 2.11 & Brazil & 3.87 & Italy & 4.37 & Tunisia & 7.71 & Tunisia & 1.24 & and & 9.93 & Spain & 27.58 & Greece & 1.13 \\
\hline Russia & 2.82 & $\begin{array}{l}\text { Ireland } \\
\end{array}$ & 2.05 & Germany & 3.26 & Holland & 2.58 & Libya & 1.99 & France & 6.25 & Morocco & 2.87 & Israel & 2.30 & Jordan & 10.79 \\
\hline Poland & 2.48 & Brazil & 2.00 & U.K & 2.58 & France & 2.59 & Morocco & 1.78 & Poland & 6.84 & Venezuela & 6.00 & Jordan & 19.27 & Holland & 2.69 \\
\hline Italy & 1.92 & U. $\mathrm{K}$ & 1.77 & Taiwan & 0.67 & Saudi & 1.16 & Israel & 15.79 & Brazil & 3.42 & America & 6.43 & Argentina & 1.57 & Italy & 5.81 \\
\hline
\end{tabular}

Source: collected and calculated from: Central Agency for Public Mobilization and Statistics, Bulletins of the Foreign Trade, www.capmas.gov.eg

For the marjoram, showing a concentration geographic exports from the plant marjoram, for the Pharmacy purposes, to each of Poland, Germany, USA, Italy, about $69.7 \%$, and the other of the countries about $30.3 \%$, having a concentration geographic exports from the Marjoram, non-formatted for sale Retail, for the Medicine purposes, to each of United States, Israel, Germany, France, about 65\%, and the other of the countries about $35 \%$, having a concentration geographic exports from the plant Marjoram, formatted for retail sale, for the Medicine purposes, to each of Germany, United States of America, Poland, France, about 61.3\%, and the other of the countries about $38.7 \%$ 
For the plant Eshieh, showing a concentration geographic exports from the Eshieh, for the Pharmacy purposes, to each of Germany, the Republic of Latvia, Netherlands, United States, about $60 \%$, and the rest of the states, about $40 \%$, having a concentration geographic exports from the Eshieh, non-formatted retail, for the Medicine purposes, to each of Spain, Russia, Jordan, Republic of Latvia, about $78.8 \%$, and the other of the countries about $21.2 \%$, having a concentration geographic exports from the Eshieh, formatted for retail sale, for the Medicine purposes, to each of Spain, Germany, Jordan, Italy, about 58.8\%, and the other of the countries about $41.2 \%$.

\section{Forecasting an area, production, amount and the value of medicinal and aromatic crops exports in Egypt until 2020 using Box-Jenkins model}

This part is designed for forecasting the area, production, quantity and the value of medicinal and aromatic plants exports in Egypt until 2020, by selecting the best methods used in the forecasting by using Box Jenkins model "Autoregressive Integrated Moving Average "(ARIMA), so we can identify the potential changes in the coming years, which is useful in the production policies, and helping to achieve food security in Egypt. Where comprises forecasting model, arranged Autoregressive[AR (P)],Moving Average[MA (q)], and the differences (d) - as shown in table No. (14).

Through the examination of models that have been estimation from the area, production, the amount and value of medicinal and aromatic plants exports in Egypt, it turns out that models respectively ARIMA $(2,0,2),(2,1,1),(0,0,2)(2.1 .2)$ more convenient, by the results of the tests described in the table (14), and by taking a residuals of the estimated model, which shows that the autocorrelation coefficient, and the partial correlation, the shape of autocorrelation for these residuals are all situated within a period $95 \%$ confidence interval, this means that the autocorrelation between the limits of random limit was not significant, therefore the model is appropriate.

Table (14) Standards and Tests to choose the Best Forecasting Models

\begin{tabular}{|c|c|c|c|}
\hline \multirow[b]{2}{*}{ Variable } & \multirow[b]{2}{*}{ Model } & \multicolumn{2}{|c|}{ Measures - statistical tests } \\
\hline & & RMSE* & $\begin{array}{l}\text { U.Theil Inequality } \\
\text { Coefficient }\end{array}$ \\
\hline Medicinal and Aromatic Plants space & $(2,0,2)$ & 3.91 & 0.032 \\
\hline Production of medicinal and aromatic plants & $(2,1,1)$ & 38.46 & 0.065 \\
\hline $\begin{array}{l}\text { The amount of medicinal and aromatic plants } \\
\text { exports }\end{array}$ & $(0,0,2)$ & 2.73 & 0.086 \\
\hline The value of medicinal and aromatic plants exports & $(2,1,2)$ & 38.18 & 0.152 \\
\hline
\end{tabular}

RMSE* Root Mean Square Error:

U- Thiel test used to test the extent of matching the estimated values with the actual values and the extent of simulated with the reality of the data, where:

$h$ : reflect the length of the chain $u$ : between $(0 \leq u \leq 1)$, and there is a complete forecasting when $u=0$

Source: collected and calculated from the table data (1) in research by using program E- views 6.

It is clear from the forecasting results for area of medicinal and aromatic plants in Egypt, in the table No.(15), it will reach about 61.6 thousand acres in 2018, where he will remain relatively stable until 2020, an increasing about $2.5 \%$ from 2014 , 
Exports of Medicinal and Aromatic Crops

while the medicinal and aromatic production, will reach about 421.7 thousand tons in 2018 , and then will increasing about 432.9 thousand tons in 2020, an increase of about $9.5 \%$ from 2014 , while the quantity exported from the medicinal and aromatic plants, will amount to about 15.7 thousand tons in 2018, where he will remain fixed relatively until 2020, an increasing about $50.9 \%$ from 2013, also shows that the medicinal and aromatic plants exports value will amount about 185.3 million pounds in 2018, and then will increase about 208.7 million pounds in 2020 an increasing about $67.8 \%$ from 2013 .

The results showed that the ARIMA model $(2,0,2)$, is the best models for forecasting an area of medicinal and aromatic plants in Egypt, and the model ARIMA $(2,1,1)$, is the best models for forecasting the production of medicinal and aromatic plants, while showing that the model ARIMA $(0,0,2)$, is the best models for forecasting the amount of medicinal and aromatic plants exports, and the model ARIMA (2.1.2), is the best models for forecasting the value of medicinal and aromatic plants exports, and the results showed the efficiency of these models, and estimated parameters in the forecasting process, based on the analysis of residuals (error).The results were closer to reality

Table (15) Results the best forecasting for dynamic models by using Box-Jenkins model

\begin{tabular}{|c|c|c|c|c|}
\hline Year & $\begin{array}{c}\text { Area of medicinal } \\
\text { and aromatic plants }\end{array}$ & production & $\begin{array}{c}\text { exports quantity of } \\
\text { medicinal and } \\
\text { aromatic plants }\end{array}$ & $\begin{array}{c}\text { exports value of } \\
\text { medicinal and } \\
\text { aromatic plants }\end{array}$ \\
\hline $\mathbf{2 0 1 8}$ & 61.6 & 421.7 & 15.7 & 185.3 \\
\hline $\mathbf{2 0 1 9}$ & 61.6 & 422.3 & 15.7 & 196.7 \\
\hline $\mathbf{2 0 2 0}$ & 61.6 & 432.9 & 15.7 & 208.7 \\
\hline
\end{tabular}

Source: collected and calculated from the table data (1) in research by using program E- views 6.

\section{Summary And Recommendations}

The paper aims to study stake of exports of the most important medicinal and aromatic crops, which include (coriander, cumin, fennel, anise, marjoram, caraway, Eshieh, mint, jasmine, hibiscus) through: studying the present for some medicinal and aromatic crops, estimating the Egyptian exports quantity, from the most important medicinal and aromatic crops, studying thengeographical distribution of Egyptian exports, which using in pharmacy, medicine field for the main importing countries, estimating the Gini coefficient - Hirschman criteria to calculate the degree of geographic concentration to the Egyptian exports from the most important medicinal and aromatic crops which using in pharmacy,medicine field to the main importing countries during the period (2008-2014), and forecasting with production ,area, quantity and value of the most important Egyptian exports of medicinal and aromatic crops until 2020.

The results have shown decreasing in the rates of change for the quantity of exports for most of medicinal and aromatic crops with the exception of (cumin, caraway and hibiscus).

The results have shown estimating stability in the quantity and value of Egyptian exports of medicinal and aromatic cropsduring the period (2000-2014), 
unsteadiness and instability to the quantity and value of Egyptian exports of medicinal and aromatic crops during the study period.

The results have also shown of the geographical distribution, for Egyptian exports of the most important medicinal and aromatic crops, whether for the Pharmacy purposes or Medicine purposes, non-formatted for sale and formatted for retail sale for the Medicine purposes, to the main importing countries during the period (2008-2014): the Export price for pharmacy purposes exceeds the Medicine purposes in each of basil and Eshieh, with the exception of marjoram, it has been shown that the export ton price for the Marjoram, non-formatted for retail sale for the Medicine purposes more than the Pharmacy purposes, and this calls for needing to focus on directing for the cultivation of those crops for sale for the Pharmacy purposes.

The results have shown estimating the Gini Coefficient - Hirschman, to calculate the degree of geographical concentration from the Egyptian exports to the most important medicinal and aromatic crops, which using in the pharmacy, medicine field to the main importing countries during the period (2000-2014): For basil it has been shown the presence of geographic concentration for the Egyptian exports from basil for the Pharmacy purposes to both countries of United States, Germany, Canada, France to about $72.9 \%$, while the countries represented about $27.1 \%$, presence of geographic concentration from the basil exports non-formatted for retail sale for medicine the purposes to both countries United States of America, France, Italy, Turkey to about $74 \%$, while the countries represented about $26 \%$, presence of geographic concentration for the basil exports formatted for retail sale for the medicine purposes to both countries United States, France, Brazil, Netherlands was about $73.1 \%$, while the other countries represented $26.9 \%$.

As for the Marjoram having geographic concentration for exports from the marjoram for the Pharmacy purposes to each of Poland, Germany, United States, Italy has been shown was about $69.7 \%$, while the other countries represented about $30.3 \%$, presence of geographic concentration for exports from Marjoram nonformatted for retail sale for the medicine purposes to both of United States, Israel, Germany, France to about $65 \%$, while the other countries represented about $35 \%$, presence of geographic concentration for exports from Marjoram formatted for retail sale for the medicine purposes to each of Germany, USA, Poland, France to about $61.3 \%$, while the other countries represented $38.7 \%$.

As for the Eshieh having geographic concentration for exports from the Eshieh for the Pharmacy purposes to each of Germany, the Republic of Latvia, Netherlands, United States has turned out was around $60 \%$, while the other countries represented about $40 \%$, having geographic concentration for exports from Eshieh non-formatted for retail sale for the medicine purposes to each of Spain, Russia, Jordan, Republic of Latvia to about $78.8 \%$, while the other countries represented about $21.2 \%$, the presence of concentration geographic for exports from Eshieh formatted for retail sale for the medicine purposes to each of Spain, Germany, Jordan, Italy about 58.8\%, while the other countries represented $41.2 \%$. 
Exports of Medicinal and Aromatic Crops

While the results of the estimation of forecasting an area, production, quantity, and the exports value of medicinal and aromatic crops exports and others, in Egypt using Box-Jenkins methodology during the period (2017-2020) is expected to occur:

1- The relative stability in the cultivated area of medicinal and aromatic crops in Egypt amounted to about 61.6 thousand acres in 2020.

2 - Increasing in the production of the medicinal and aromatic crops in 2020 by about $9.5 \%$ from 2014.

3- The relative stability in the amount of medicinal and aromatic crops in Egypt's exports amounted to about 15.7 thousand tons in 2020 .

4- Increasing the export value for the medicinal and aromatic crops in 2020 of about $67.8 \%$ from 2013 .

\section{In light of the results obtained, the search is recommended that:}

1- Education to the farmers to grow the export medicinal and aromatic plants, leading to increased production and stabilization of the quantity and value of exports of those crops, where it was found unsteadiness and instability to the quantity and value of Egyptian exports of those crops.

2- Needing for the necessary attention to cultivation of medicinal and aromatic crops for Pharmacy purposes, where it was found that the price of a ton of export for use the Pharmacy purposes of exceeds similar for the Medicine purposes.

3- The opening of new markets, especially in the Arab countries of medicinal and aromatic plants, which show a geographic concentration of most of Egypt's exports of medicinal and aromatic crops in the European Union and United States markets.

4- Needing to develop a proposed policy for the vertical and horizontal expansion in the cultivation and production of medicinal and aromatic crops which show a relative stability in the cultivated medicinal and aromatic plants area in Egypt by 2020.

\section{References:}

1. Abdel HadyHamza and others - instability coefficient of the most important Egyptian exports of medicinal and aromatic crops, Egyptian Journal of Agricultural Economics, Volume XXV, Issue IV, December 2015.

2. Aladdin Said Shabrawy, SorayaSadek Fred-economic study of some medicinal and aromatic crops, Egyptian Journal of Agricultural Economics, vol. XVIII, No. IV, in December 2008.

3. AmalZine El Abidine-economic Study for the production and export crop chamomile in Egypt, Egyptian Journal of Agricultural Economics, Vol. V xx, fourth edition, December 2015.

4. Ayman Abdel-Abdulqawi, impact of electronic commerce in the Egyptian exports development of the most important medicinal and aromatic crops, Egyptian Journal of Agricultural Economics, Vol. XX, No. IV, in December 2010.

5. Box, George, Gwilym M. Jenkins,\& Gregory C. Reinsel "Time Series Analysis : Forecasting and Control " 3rd ed, Prentice-Hall Inc.,New Jersey, USA ,1994. 
6. Dickey, David \& Wayne A. Fuller " Likelihood Ratio Statistics for Autoregressive Time Series with a Unit Root " Econometrica, Vol.49,no.4,july, 1981; 1057-1072.

7. Henderson M. James and Richard E. quandt, Micro Economic Theory, A mathematical Approach, 3rd, International Student Edition, 1980.

8. Johnston, J., Econometric Methods, 3rd, McGraw-Hill Book Company, New York, 1984.

9. Koutsoyiannis, A., Theory of Econometrics, 2nd. The Macmillan Education L.Td, 1986.

10. Ministry of Agriculture and land reclamation, Economic Affairs Sector, centralized management of the economy Alzaraei, Agricultural Statistics Bulletin, various issues.

11. Mohamed Abdel Aziz Khalil, on behalf of dos Hanna-economic study of some external demand determinants of the Egyptian exports to the most important medicinal and aromatic crops (caraway, coriander, cumin) in global markets, Egyptian Journal of Agricultural Economics, Vol. XXIV, No. IV, in December 2014.

12. Samir Sharif Fayyad, Nadia Ahmed Gharib, instability index and factors affecting it to the major Egyptian exports of medicinal and aromatic crops, Egyptian Journal of Agricultural Economics, vol. XVII, Issue I, in March 2007.

13. Samira Amin Abdul Halim and others-competitiveness of Egyptian exports from cumin, coriander, Egyptian Journal of Agricultural Economics, Volume XX, Issue IV, December 2010.

14.The website of the Central Agency for Public Mobilization and Statistics www.capmas.gov.eg 
Exports of Medicinal and Aromatic Crops

Appendix (1): Pharmaceutical uses of some Medicinal plants:

\begin{tabular}{|c|c|c|}
\hline & key actions & Traditional and current uses: \\
\hline sweet basil: & $\begin{array}{c}\text { indigestion } \\
\text { Easing flatulence \&stomach cramps. } \\
\text { Relieve nausea and vomiting } \\
\text { Sedative action } \\
\text { Increase breast milk } \\
\text { Antibacterial action } \\
\end{array}$ & $\begin{array}{l}\text { Kill intestinal worm. } \\
\text { Depression, anexiety and insomnia. } \\
\text { Epilepsy, migraine and whooping cough. } \\
\text { Externally act as insect repellant. }\end{array}$ \\
\hline Holy basil: & $\begin{array}{c}\text { Lowers blood suger level. } \\
\text { Antispasmodic. } \\
\text { Analgesic. } \\
\text { Lowers blood pressure. } \\
\text { Reduces fever. } \\
\text { Anti inflammatory. } \\
\end{array}$ & $\begin{array}{l}\text { Tonic and improves vitality. } \\
\text { Prevents infection and controls high fever. } \\
\text { Reduces stress and adaptogenic. } \\
\text { Stabilize blood suger so used in diabites. } \\
\text { Treatment of ashthma\&cough \& bronchitis. } \\
\text { Helps cankar sores to heal. }\end{array}$ \\
\hline $\begin{array}{l}\text { Levant } \\
\text { Wormwood: }\end{array}$ & $\begin{array}{c}\text { santonin (toxic to roundworm) } \\
\text { volatile oils }\end{array}$ & $\begin{array}{c}\text { Expel worms. } \\
\text { Tonic and stimulant effect on digestion. } \\
\text { Loss of appetite. }\end{array}$ \\
\hline Mugwort: & $\begin{array}{l}\text { Volatile oils. } \\
\text { Flavonoids. } \\
\text { Coumarinderevatives. } \\
\text { Triterpenes. }\end{array}$ & $\begin{array}{c}\text { Digestive and tonic herb. } \\
\text { Improves appetite, digestive function and } \\
\text { absorption. } \\
\text { Elimination of worms. } \\
\text { Reduces menstrual bleeding. }\end{array}$ \\
\hline marjorm: & $\begin{array}{c}\text { Stimulant. } \\
\text { Antispasmodic prop. } \\
\text { Relieve anexiety, headache and insomnia. }\end{array}$ & $\begin{array}{c}\text { Gastro intestinal flatulance and colic. } \\
\text { C.N.S anexioletec action. } \\
\text { General tonic. }\end{array}$ \\
\hline Caraway: & $\begin{array}{l}\text { antispasmodic } \\
\text { carminative } \\
\text { sweeten the breath } \\
\text { improve appetit } \\
\text { expectorant }\end{array}$ & $\begin{array}{l}\text { Digestive problems. } \\
\text { Anti spamsodic. } \\
\text { Bronchitis and in cough remedies. }\end{array}$ \\
\hline Coriander: & $\begin{array}{l}\text { flatulance } \\
\text { bloating } \\
\text { cramps } \\
\text { rheumatic pain }\end{array}$ & $\begin{array}{l}\text { Digestive problems } \\
\text { Anti spamsodic } \\
\text { Relief nervous tension } \\
\text { Relief rheumatic pain } \\
\text { Aphrodesiac }\end{array}$ \\
\hline Cumin & $\begin{array}{c}\text { flatulance } \\
\text { bloating } \\
\text { digestive process }\end{array}$ & $\begin{array}{l}\text { Improve digestion } \\
\text { Relaxes the gut } \\
\text { Certain types of tumers }\end{array}$ \\
\hline Fennel: & $\begin{array}{l}\text { relieve bloating } \\
\text { stomach pain } \\
\text { stimulate appetite } \\
\text { anti inflammatory }\end{array}$ & $\begin{array}{c}\text { Digestive system } \\
\text { Kidney stones } \\
\text { Urinary antiseptic } \\
\text { Mild expectorant } \\
\text { Increase breast milk production } \\
\text { Conjunctivities }\end{array}$ \\
\hline Jasmine & $\begin{array}{l}\text { calming and sedative effect } \\
\text { soothing effect }\end{array}$ & $\begin{array}{c}\text { Antidepressant and relaxing } \\
\text { Relieve tension } \\
\text { Externally Soothing dry and sensetive skin }\end{array}$ \\
\hline Hibiscus: & $\begin{array}{l}\text { Laxative effect. } \\
\text { Relaxing effect on the uterine musculature. } \\
\text { Antispasmodic } \\
\text { Ant hypertension }\end{array}$ & $\begin{array}{c}\text { Gastrointestinal spasm, constipation. } \\
\text { Stimulate appetite. } \\
\text { Gastroenteritis. } \\
\text { fragility, varicose veins and } \\
\text { hemorrhoids. } \\
\text { C.N.S anexity and insomnia. }\end{array}$ \\
\hline Anise: & $\begin{array}{l}\text { stimulate of sexual drive } \\
\text { stimulate breast milk production }\end{array}$ & $\begin{array}{l}\text { G.I.T indigestion, reduce gas and bloating. } \\
\text { Relieve infant and children colic. } \\
\text { Counteracting menstrual pain } \\
\text { Respiratory tract: whooping cough, bronchitis } \\
\text { and asthma. }\end{array}$ \\
\hline Peppermint & $\begin{array}{c}\text { carminative } \\
\text { relieve muscle spasm } \\
\text { increase sweating } \\
\text { stimulate secretion of bile } \\
\text { antiseptic } \\
\end{array}$ & \\
\hline
\end{tabular}

Source: collected from :

1- Encyclopedia of medicinal plants, www.encyclopedia.com.

2- Extraction technology for medicinal and aromatic plants.

3-medicinal plants classification, biosynthesis and pharmacology. 


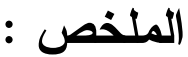

يستهدف هذا البحث در اسة صادر ات أهم محاصيل النباتات الطبية و العطرية و التي تشمل كـلـ مـن (الكسبرة، الكمون، الثمر، اليانسون، الكراوية، الثيح، النعناع، الياسمين، الكركدية) من خلال در اسة الوضع الر اهن لبعض محاصيل النباتات الطبية والعطرية، تقدير معامل الاستقر ار لكمية الصادر ات المصرية من أهم النباتات الطبية و العطرية، در اسة التوزيع الجغر افي للصـادرات المصرية لأهم النباتــات الطبيـــة و العطريـــة المستخدمة في مجال الصيدلة و الطب لأهم الدول المستوردة، تقدير معامل جيني - هيرشمان لحساب درجــة التركز الجغر افي للصادر ات المصرية لأهم النباتات الطبية و العطرية المستخدمة في مجال الصيدلة و الطــب هئب

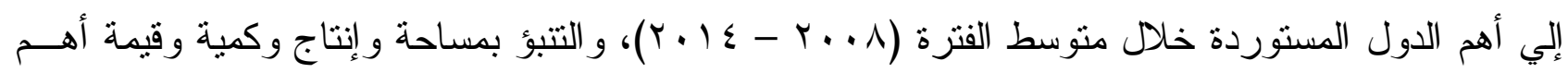

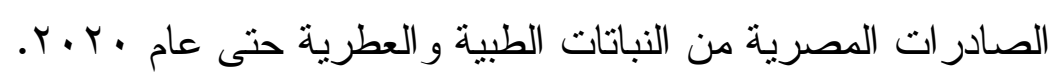
وقد أوضحت نتائج تقدير معادلات الاتجاه العام الزمني للصادر ات المصرية من محاصــيل النباتـات

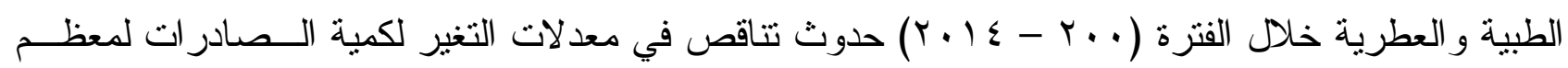
محاصيل النباتات الطبية و العطرية فيما عدا (الكمون، الكر اوية، الكركدية). وقد أوضحت نتائج تقدير عدم الاستقر ار لكمية وقيمة الصادر ات المــصرية مــن النباتـات الطبيــة

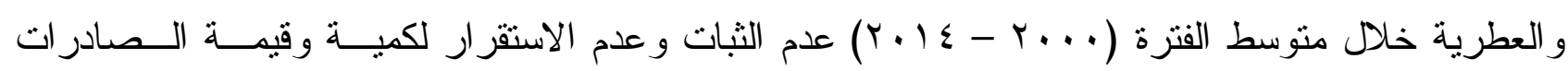
المصرية دن النباتات الطبية و العطرية خلال فترة الدر اسة. وقد أوضحت نتائج در اسة التوزيع الجغر افي للصادر ات المصرية من أهم النباتات الطبية و العطريـــة

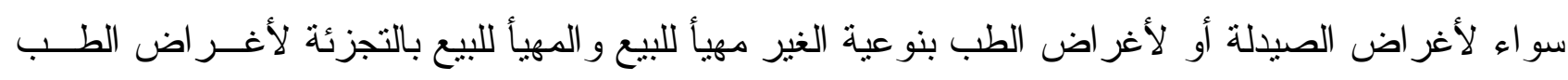

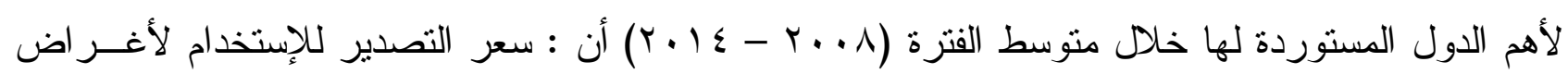
الصيدلة يفوق مثيلة لأغر اض الطب في كل من الريحان والثيح، فيما عدا البردقوش فقد تبين أن سعر طـن

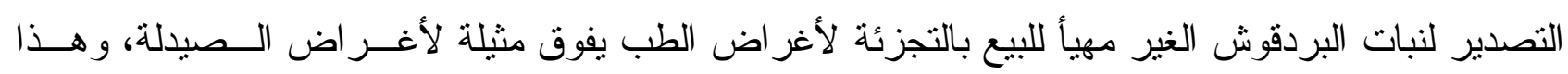
يدعو إلي ضرورة توجيه الاهتمام اللازم لزر اعة تلك النباتات للبيع لأغر اض الصيدلة.

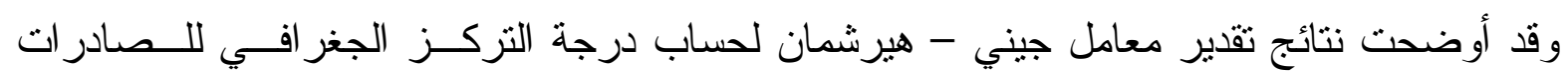
المصرية لأهم النباتات الطبية و العطرية المستخدمة في مجال الصيدلة والطب إلي أهم الدول المستوردة خلال

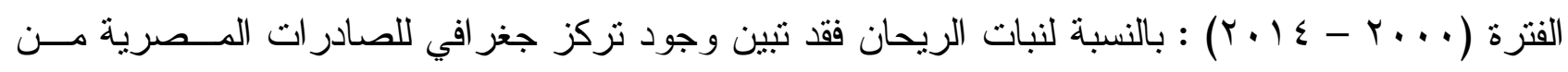

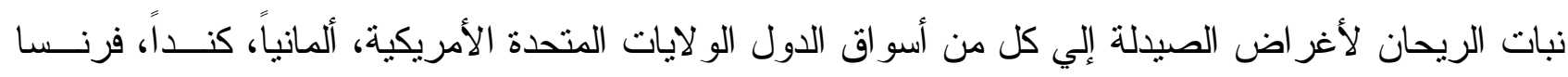

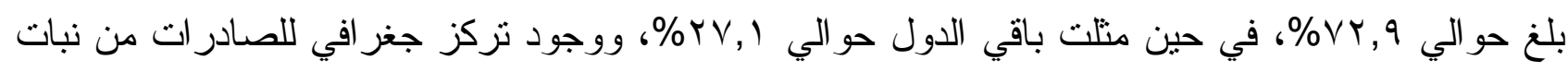

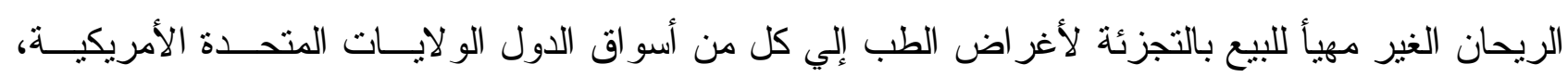

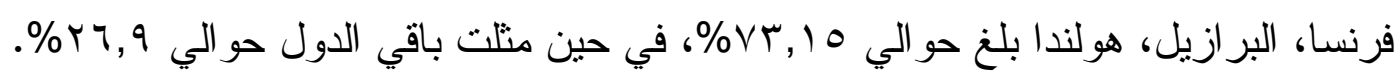
أما بالنسبة لنبات البردقوش فقد تبين وجود تركز جغر افي للصادر ات من نبات البردقوش لأغـــر اض بـ لاض

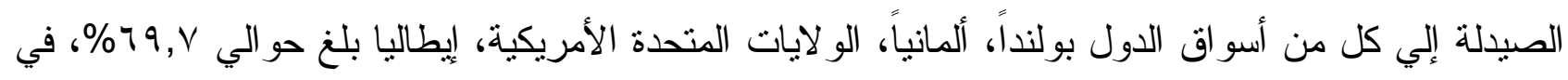

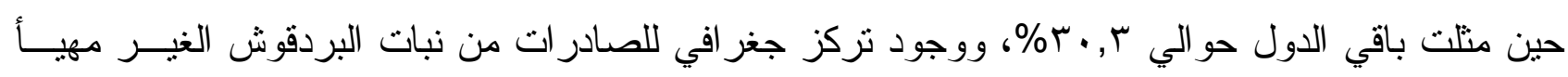


للبيع بالتجزئة لأغر اض الطلب إلي كل من أسو اق الدول الو لايات المتحدة الأمريكية، إسر ائيل، ألمانياً فرنسـسا

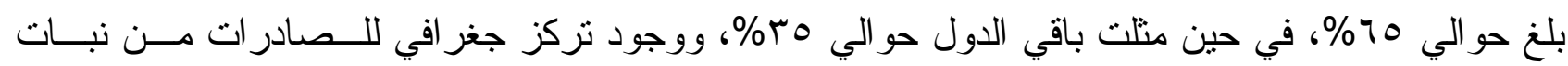

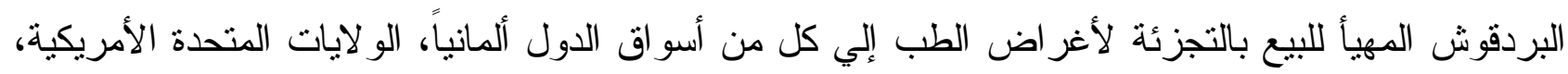

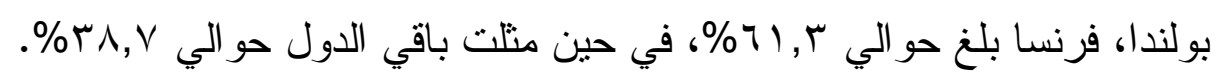

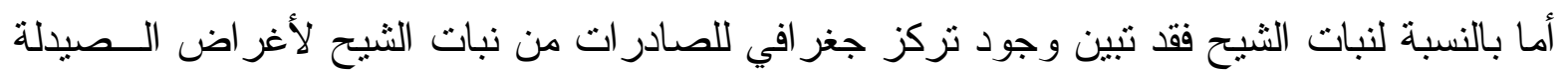

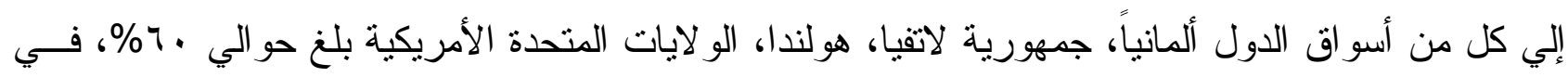

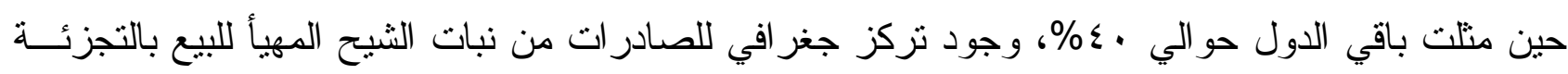

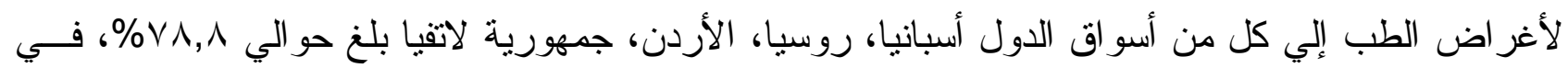

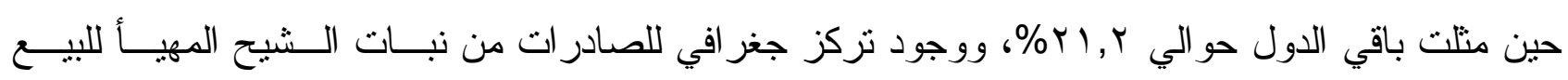

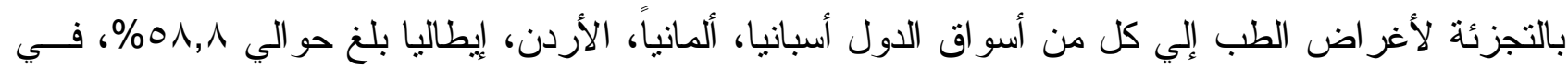

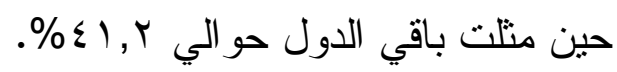

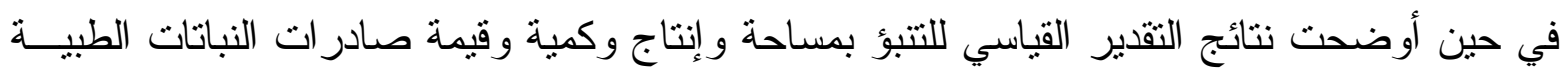

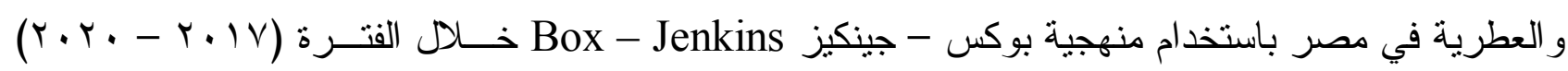

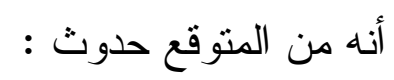
1- ثبات نسبي في المساحة المزروعة بالنباتات الطبية و العطرية في مصر بلغت حو الي ؟ ب, اب ألــف فــدان

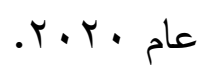

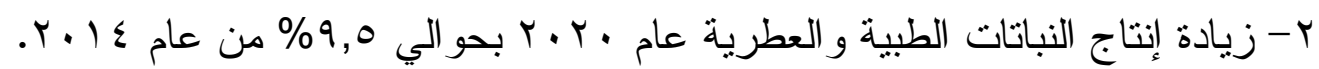

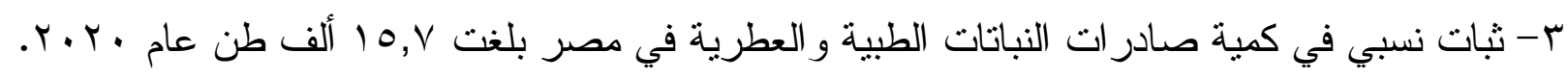

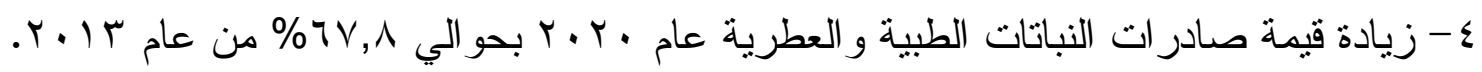

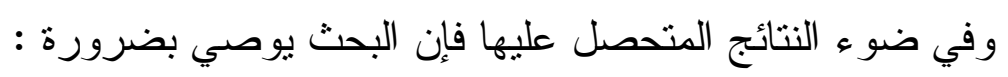

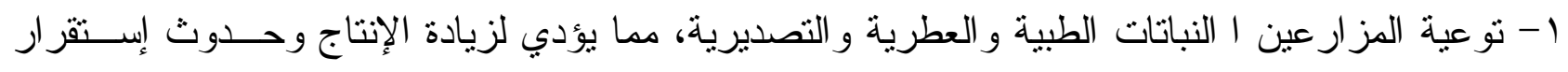

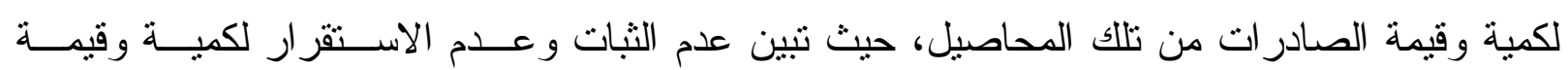
الصادر ات المصرية من تلاك المحاصيل.

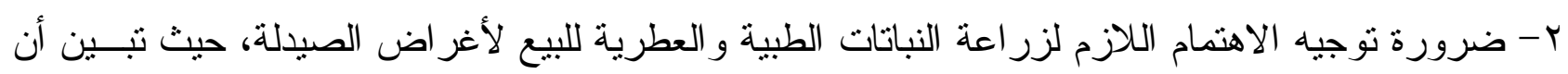

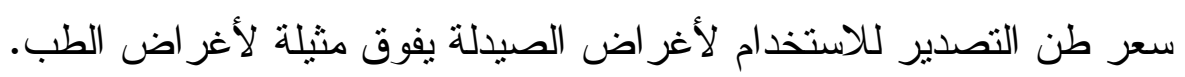

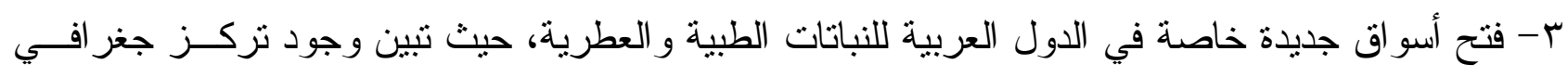

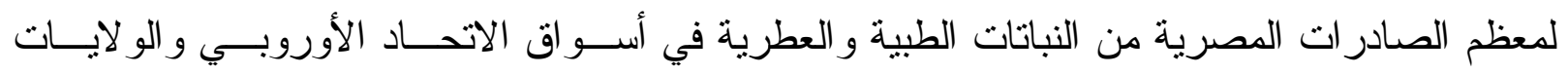
المتحدة الأمريكية.

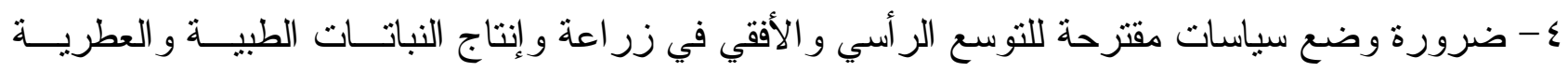

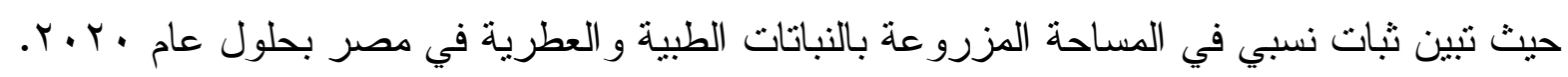

